\title{
A Dimensional Analysis of the Relationship between Communication Satisfaction and Turnover Intention: The Mediating Role of Organizational Commitment
}

\author{
Norizah Mustamil ${ }^{1}$, Amir M. T. Yazdi ${ }^{1}$, Saw Sze Syeh ${ }^{1} \&$ Muhammad AsriMohd Ali ${ }^{2}$ \\ ${ }^{1}$ Department of Business Strategy and Policy, Faculty of Business and Accountancy Building, University of \\ Malaya, 50603 Kuala Lumpur, Malaysia \\ ${ }^{2}$ Department of Administrative Studies and Politics, Faculty of Economics and Administration Building, \\ University of Malaya, 50603 Kuala Lumpur, Malaysia \\ Correspondence: Norizah Mustamil, Department of Business Strategy and Policy, Faculty of Business and \\ Accountancy Building, University of Malaya, 50603 Kuala Lumpur, Malaysia. Tel:60-379-673-949. E-mail: \\ norizahmm@um.edu.my
}

Received: July 2, 2014

Accepted: July 28, 2014

Online Published: August 22, 2014

doi:10.5539/ijbm.v9n9p75

URL: http://dx.doi.org/10.5539/ijbm.v9n9p75

\begin{abstract}
By taking into consideration the significant increase in turnover rate in the recent years, we aimed to expand our understanding of the factors influencing employees' decision to leave the organization and consequently to provide managers and Human Resource Development (HRD) practitioners with more information to better manage employees' undesirable turnover. Thus, the relationship between the theoretically related communication satisfaction's dimensions and turnover intention was analyzed. A sample of 181 employees working in 11 industries of all three economic sectors was selected for the analysis. Among the five tested dimensions, personal feedback, supervisory communication, and communication climate were found to be significantly related to turnover intention. Unexpectedly, organizational integration and co-workers communication were not significantly related to turnover intention. Additionally, the relationship between supervisory communication and turnover intention was found to be partially mediated by the employees' affective commitment. Therefore, by keeping employees well-informed about their performance, facilitating the flow of upward and downward communication between employees and their supervisors, and finally by improving communication climate in the organization, managers will have better chance in preventing employees' voluntary turnovers.
\end{abstract}

Keywords: turnover intention, communication satisfaction, organizational commitment

\section{Introduction}

Given the importance of retaining knowledgeable workers and talents in the 21st century, identifying the factors which influence turnover intention can benefit organizations significantly. In recent years, companies have experienced significant increase in the turnover rate which has given rise to a serious concern. A survey by Tower Watson, reported in the Borneo Post Online (2011), has shown that the turnover rate in Malaysia almost doubled in 2011 with an increase rate of 16 percent compared to the year before. The high turnover rate has prompted employers, especially Human Resource Development (HRD) practitioners, to desperately look for possible solutions.

It is almost common knowledge that understanding and reducing the employees' turnover can benefit organizations in many ways. High turnover is synonymous with losing valuable skills, talents, abilities, and knowledge (Ballinger et al., 2011; Shaw et al., 2005). Summers et al. (2012) provided evidence that not only turnover produces flux in coordination and disrupts the existing organizational interaction, but it also diverts the resources toward non-productive activities. Furthermore, by increasing replacement cost and consequently lowering potential financial gain, turnover can significantly damage organizational performance (Cascio, 2006).

There is tremendously higher number of empirical turnover-related studies conducted in recent years; they showed that almost two third of empirical studies on turnover have been conducted in the last decade and this is an indication of the growing interest on the topic (Heavey et al., 2013). The growing interest can be attributed to recent trends such as technological advancement, globalization, and increase in knowledge-based work, which 
make it crucial for organizations to keep high quality employees now more than ever (Holtom et al., 2008). Despite the fact that the relationship between communication satisfaction and turnover or turnover intention has been tested by handful of studies (Tsai et al., 2009), the need for a dimensional analysis, which expands understanding about the effect of each aspect of communication satisfaction on turnover intention, has not been addressed.

\section{Turnover}

Turnover can simply be defined as employees' departure from the organization(March \& Simon, 1958). The first turnover-related studies were conducted almost a century ago, when Fish (1917) and Greenwood (1919) assessed "stability of employment" and "rate of departure" respectively (Heavey et al., 2013). From then on, turnover including its antecedents and organizational outcomes has been studied extensively. Within the management literatures, turnover, both voluntary (where employees decide to quit) and involuntary turnover (where employer decide to terminate the employees) had been analyzed at various levels, namely the individual, group, and organization level of analysis (Shaw et al., 1998).

One of the most established negative outcomes of turnover is the damage to organizational performance comprising cost effectiveness and productivity. Throughout the literature, the impact of turnover on organizational performance has been explained by three perspectives: cost-based, human capital, and social capital perspectives (Hancock et al., 2013; Heavey et al., 2013). Turnover negatively influences organizational performance by increasing the cost-based perspective which includes the direct and indirect costs (Allen, Bryant, \& Vardaman, 2010). In addition, the human capital perspective denotes that by removing the valuable skills and knowledge which were gained through years of experience and training, turnover can negatively affect the organizational performance (Dess \& Shaw, 2001). Finally, the social capital perspective states that when employees exit, organizations lose valuable social relationships, which in turn can significantly damage the organizational performance (Holtom, Mitchell, Lee, \& Eberly, 2008).

Moreover, by conducting a meta-analytic assessment on 82 empirical studies, Heavey et al. (2013) reported significant association between collective turnover which includes employee departures at unit, group, and organization level of analysis (Hausknecht \& Trevor, 2011) and production efficiency, counter-productivity, profit margin, customer satisfaction, error or loss rate, and sales efficiency. In terms of antecedents, Heavey et al. (2013) identified HRM inducement (e.g., internal mobility and high participation work design), employees' attitude (e.g., job satisfaction), and demographic variables (e.g., age and tenure) as significant predictors of collective turnover.

\section{Organizational Commitment}

Organizational commitment refers to the degree to which employees are apt to remain in the organization and share its values, and the extent to which they are proud of working in their organization (Mowday, Steers, \& Porte, 1979) In their famous book, commitment in the workplace, Meyer and Allen (1997) proposed a three-component model of commitment, which has dominated the literature of organizational commitment. By going through the previous research, Meyer and Allen (1997) noted that researchers had regarded organizational commitment as three distinct mindsets (affective/attitudinal, continuous, and normative commitment). Affective commitment, which is rooted in Kanter's (1968) "cohesion commitment", denotes the employees' emotional attachment to the organization. In other words, affectively committed employees tend to enjoy their membership and identify themselves with their organizations (Allen \& Meyer, 1990). Organizational commitment has also been regarded as employees' inclination to continue their job activities (continuous commitment) as a result of perceived costs of departing the organization (Jaros, 2007). Organizational commitment may also be accounted for by one's perceived obligation toward the organization (normative commitment). Thus, normatively committed employees engage in consistent work activities because of the internalized normative pressure they feel, or simply because they feel it is the "right" thing to do (Allen \& Meyer, 1990).

In 1990, Mathieu and Zajac reviewed empirical studies related to general organizational commitment and conducted a meta- analysis on over 200 studies. They identified personal characteristics (e.g., perceived competence, job level, and salary), job characteristics (e.g., job scope, challenge, and skill variety), and role states (e.g., role conflict and role ambiguity, among others as established antecedents of organizational commitment. Furthermore, Mathieu and Zajac (1990) identified job performance, intention to search for alternative jobs, intention to leave/ turnover intention, and turnover, among others as established outcomes of organizational commitment.

Later on, Meyer et al. (2002) conducted a meta- analysis for all three components of organizational commitment. They also identified role ambiguity, role conflict, age, tenure, and work experience, among others as significant 
antecedents of all three components of organizational commitment (e.g., affective, continuous, and normative). Additionally, Meyer et al. (2002) found significant association between all three mindsets of organizational commitment and both turnover and turnover intention or withdrawal behavior.

\section{Communication Satisfaction}

Prior to 1977, when Downs and Hazen conceptualized a multidimensional construct of "communication satisfaction", satisfaction with organizational communication had been measured uni-dimensionally (Deconinck et al., 2008). By conducting principal component factor analysis on 88 related items, Downs and Hazen (1977) identified 8 distinct factors. Thus, communication satisfaction has been defined as the degree to which individuals are satisfied with the different aspects of organizational communication at the personal, group, and organizational level (Hecht, 1978; Mueller \& Lee, 2002) Communication satisfaction encompasses satisfaction with communication climate, supervisory communication, organizational integration, media quality, co-worker communication, corporate information, personal feedback, and subordinate communication (Downs \& Hazen, 1977).

Communication climate, which reflects the satisfaction on both the personal and organizational level, denotes the degree to which employees are satisfied with different issues such as motivating aspect, attitude toward communication, and problem understanding. Supervisory communication (i.e., communication on personal level) comprises both upward and downward communication with supervisors. Organizational integration (i.e., communication on group level) refers to the degree to which employees receive information about their work environment and organization. Media quality, which reflects the satisfaction on organizational level, revolves around employees' satisfaction with the effectiveness of company's media. Co-worker communication is a group-level satisfaction, which is the outcome of employees' perception towards the flow of informal and horizontal communication. Corporate information (i.e., satisfaction experienced on organizational level) reflects employees' satisfaction with information associated with overall functioning of the organization. Personal feedback (i.e., satisfaction on personal level) is accounted for by the degree to which employees understand the performance procedure. Finally, subordinate communication (i.e., satisfaction on personal level), is a summation of supervisors' satisfaction with different issues such as subordinates' responsiveness to downward communication and communication overload (Deconinck et al., 2008; Downs \& Hazen, 1977; Mueller \& Lee, 2002).

\section{Hypotheses Development}

\subsection{Personal Feedback}

As was explained earlier, personal feedback revolves around the employees' propensity to know about their performances. Personal feedback is almost identical with one of Hackman and Oldham's (1975) job design facets (i.e. feedback from agents) which are a foundation in the development of Job Characteristics Model (JCM) Job feedback (i.e., the degree to which supervisors/managers communicate with their subordinates about their performance; McKnight et al., 2009), as one of five components of Job Characteristics Model (JCM), has been tested by some empirical studies as an antecedent of turnover intention. For instance, Spector and Jex (1991) found negative significant association between feedback, as a component of JCM, and the employees' intention to leave the organization. McKnight et al. (2009) also identified all the job characteristics, including the feedback, as significant predictors of turnover intention. Martin (1979) reported that instrumental communication (i.e., the degree to which information about role performance is transmitted to the members of the organization) significantly predicts the turnover intention. Therefore, we can hypothesize that:

H1: Personal feedback significantly relates to turnover intention

\subsection{Supervisory Communication}

The effect of the upward and downward communication between supervisors and subordinates (i.e., supervisory communication) on employees' withdrawal behaviors, including turnover intention, has been assessed in some studies. For instance, by conducting an exploratory study, Timm (1978) showed that employees, who perceive inequity in the supervisory communication, both upward and downward, tend to respond with withdrawal behaviors such as turnover intention. In addition, Kim (2012) maintained that IT professionals who perceive ineffectiveness in supervisory communication show higher degree of turnover intention.

Based on the four empirical studies, Mathieu and Zajac (1990) found significant relationship between leader or supervisor communication and organizational commitment (mean corrected correlation $\left[r_{c}\right]=.454$ ). They justified this relationship by the fact that timely and accurate supervisory communication improves the work environment and consequently boosts employees' commitment to their organization. In their meta-analysis, 
Mathieu and Zajac (1990) also identified "intention to leave/turnover intention" (number of empirical studies [K] $=36$, mean corrected correlation $\left[r_{c}\right]=-.464$ ) as a significant outcome of organizational commitment. Griffeth et al. (2000) also identified organizational commitment as an established antecedent of turnover $\left(K=64, r_{c}=-.23\right)$. Furthermore, Meyer et al. (2002) conducted a meta-analytic review on commitment-related studies. They also identified turnover intention as a significant consequence of affective $\left(K=24, r_{c}=-.51\right)$, normative $\left(K=12, r_{c}=\right.$ -.39), and continuous commitment $\left(K=17, r_{c}=-.17\right)$. Brunetto et al. (2011) also found significant association between supervisor-subordinates communication and affective commitment among nurses. It is more likely that employees, who perceive both downward and upward communication with their supervisors as satisfactory communication, feel a higher degree of emotional attachment and obligation towards their organization. Thereby, based on the above evidence we hypothesized that:

H2: Supervisory communication significantly relates to turnover intention;

H3: Normative commitment mediates the relationship between supervisory communication and turnover intention;

H4: Affective commitment mediates the relationship between supervisory communication and turnover intention.

\subsection{Organizational Integration}

Organizational integration reflects the employees' satisfaction with information they received about the organization and their immediate work environment (Downs \& Hazen, 1977). Many of the empirical studies related to organizational integration had been conducted under the term "information sharing". Information-sharing, as one of human resource important practices, reinforces employees' beliefs that the organization cares about their well-being and consequently reduces the degree of turnover intention among employees (Pare \& Tremblay, 2007). By assessing the relationship between information-sharing and turnover intention among IT professionals, Pare and Tremblay (2007) found that employees' turnover intention tend to be lower when they have better access to business-related information. In addition, Pare and Tremblay (2007) found significant link between HRD practices, comprising information sharing, and affective commitment. On the other hand, Meyer et al. (2002) provided strong evidence for significant association between affective commitment and turnover intention. Thus, we hypothesized that:

H5: Organizational integration significantly relates to turnover intention;

H6: Affective commitment mediates the relationship between organizational integration and turnover intention.

\subsection{Communication Climate and Co-Workers Communication}

The relationship between both communication climate and co-workers communication, and turnover intention has been tested only by a handful of studies. Hill and Northouse (1978) held that positive communication climate negatively influences withdrawal behaviors including absenteeism, turnover, and grievance. Despite the fact that the relationship between co-worker communication and turnover intention has been appraised by some studies, their results are somewhat contradicting each other. For instance, Cox (1999) noted that co-worker or work-group communication significantly influences employees' turnover intention. On the other hand, Tourangeau et al. (2010) did not find any significant association between work-group communication and turnover intention. So, based on above-mentioned evidence, we hypothesize that:

H7: Communication climate significantly relates to turnover intention;

H8: Co-workers communication significantly relates to turnover intention;

Figure 1 below shows the summary of the hypotheses constructed in this study. 


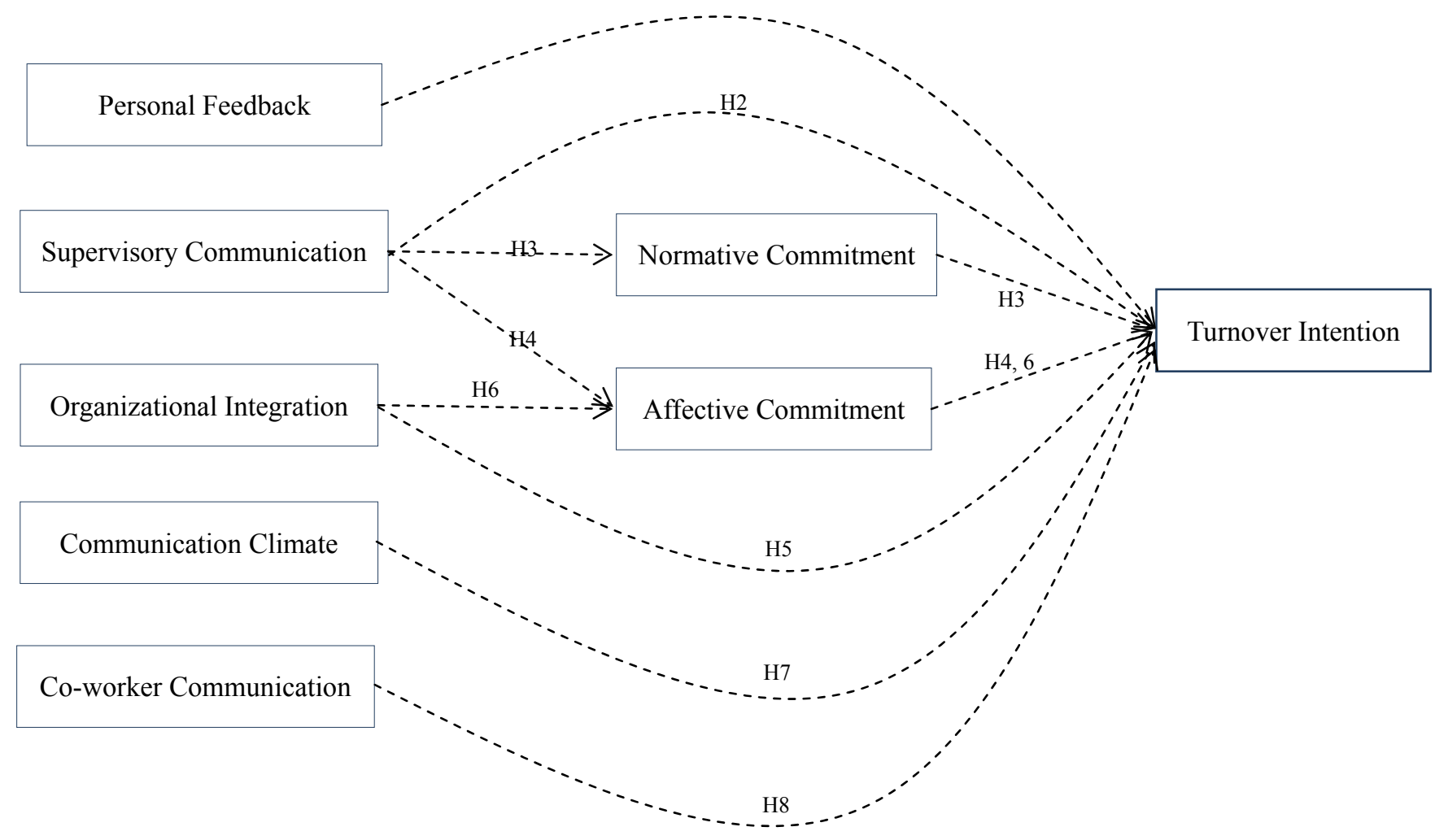

Figure1. Summary of study hypotheses

\section{Methods}

\subsection{Sample}

The sample consisted of 181 employees working in Malaysia and the response rate was 90.5 percent .Quota sampling method was employed to ensure that the sample represented the population of employees working in different industries within all economic sectors. In total, data was collected from 11 industries (e.g. hospitality, healthcare, agriculture/forestry, and product manufacturing) of all three economic sectors (i.e. primary, secondary, and tertiary sectors). Most of the sample are female (56.4\%), 21 to 30 years old (62.4\%), and had a first degree $(54.1 \%)$. The majority of sample had company and position tenure of 2 to 5 years $(46.4 \%)$ and 1 to 3 years $(44.8 \%)$ respectively (see Table 1$)$.

\subsection{Measures}

Communication satisfaction's dimensions (i.e., personal feedback $[\alpha=.874]$, supervisory communication $[\alpha=.933]$, organizational integration $[\alpha=.865]$, communication climate $[\alpha=.882]$, co-worker communication $[\alpha=.784]$ ) were measured using Downs and Hazen's (1977) instrument. Allen and Meyer's (1990) measurement instrument was adopted for assessing the level of employees' normative $(\alpha=.747)$ and affective commitment $(\alpha=.736)$. Similar to Martin's (1979) procedure, turnover intention was measured by evaluating the employees' tendency to remain as an organization member (3 Items). All the measures were in six-point Likert scale format ( $1=$ strongly disagree to $6=$ strongly agree) and they were all self-assessed.

Table 1 below shows sample's demographic profile. 
Table 1. Sample's demographic profile

\begin{tabular}{cccccccc}
\hline Demographic Variables & levels & Frequency & $\%$ & Demographic Variables & levels & Frequancy & $\%$ \\
\hline \multirow{6}{*}{ Age } & Under 20 & 1 & .6 & & Certificate & 17 & 9.4 \\
& $21-30$ & 113 & 62.4 & & Diploma & 39 & 21.5 \\
& $31-40$ & 51 & 28.2 & Education & First degree & 98 & 54.1 \\
& $41-50$ & 12 & 6.6 & & Master & 26 & 14.4 \\
& $51-60$ & 4 & 2.2 & & PhD & 1 & .6 \\
\hline \multirow{6}{*}{ Position Tenure } & less than 1 & 34 & 18.8 & & Less than 2 & 56 & 30.9 \\
& 1 to 3 years & 81 & 44.8 & & 2 to 5 years & 84 & 46.4 \\
& 3 to 5 years & 37 & 20.4 & Company Tenure & 5 to 10 years & 30 & 16.6 \\
& 5 to 10 years & 22 & 12.2 & & 10 to 15 years & 8 & 4.4 \\
& More than 10 & 7 & 3.9 & & More than 15 & 3 & 1.7 \\
\hline \multirow{6}{*}{ Gender } & Male & 79 & 43.6 & & & & \\
& Female & 102 & 56.4 & & & &
\end{tabular}

Table 2. The Result of univariate analysis and Pearson correlation

\begin{tabular}{|c|c|c|c|c|c|c|c|c|c|c|c|}
\hline & $\alpha$ & $\mu$ & S.D. & 1 & 2 & 3 & 4 & 5 & 6 & 7 & 8 \\
\hline 1. Communication Climate & 0.882 & 3.78 & .97 & 1 & & & & & & & \\
\hline 2. Supervisors Relationship & 0.933 & 3.91 & .95 & $.510^{* *}$ & 1 & & & & & & \\
\hline 3. Organizational Integration & 0.865 & 3.87 & .82 & $.516^{* *}$ & $.553^{* *}$ & 1 & & & & & \\
\hline 4. Coworker Communication & 0.784 & 3.80 & .75 & $.383^{* *}$ & $.520^{* *}$ & $.665^{* *}$ & 1 & & & & \\
\hline 5. Personal Feedback & 0.874 & 3.62 & .89 & $.469^{* *}$ & $.462^{* *}$ & $.658^{* *}$ & $.608^{* *}$ & 1 & & & \\
\hline 6. Affective Commitment & 0.736 & 3.18 & .73 & $.475^{* *}$ & $.451^{* *}$ & $.460^{* *}$ & $.418^{* *}$ & $.389^{* *}$ & 1 & & \\
\hline 7. Normative Commitment & 0.747 & 3.31 & .85 & $.299^{* *}$ & $.395^{* *}$ & $.483^{* *}$ & $.441^{* *}$ & $.490^{* *}$ & $.468^{* *}$ & 1 & \\
\hline 8. Turnover Intention & 0.911 & 3.01 & 1.25 & $-.285^{* *}$ & $-.300^{* *}$ & $-.148^{*}$ & -.129 & $-.285^{* *}$ & $-.269^{* *}$ & $-.303^{* *}$ & 1 \\
\hline
\end{tabular}

Note. ${ }^{*}$ Significant at the 0.05 level; ** Significant at the 0.01 level.

\section{Results}

Skewness and Kurtosis for all the study variables fell within the range of \pm 1 , indicating that all variables were normally distributed. The result of Confirmatory Factor Analysis (CFA) showed a good fit between data and hypothesized model $(\mathrm{GFI}=.818$, Chi-Square $/ \mathrm{df}=1.504, \mathrm{CFI}=.931 . \mathrm{PCFI}=.825, \mathrm{RMSEA}=.053)$. Harman's single factor test for assessing common method bias was employed. Harman's test indicated that single factor only explains $\% 35.5$ of all variances. Thereby, it was concluded that common method variance is not problematic. As expected, personal feedback $(\beta=-.246, \mathrm{P}<.05)$, supervisory communication $(\beta=-.243, \mathrm{P}<.01)$, and communication climate $(\beta=-.175, \mathrm{P}<.05)$ were significantly related to turnover intention (see table 3 ). Contrary to expectations, organizational integration and co-workers communication didn't show any significant association with turnover intention. Variance Inflation Factor (VIF) for all the independent variables was less than 3 (see Table 3), therefore multicollinearity was not an issue.

Table 3. The result of hierarchical regression analysis

\begin{tabular}{|c|c|c|c|}
\hline & \multicolumn{2}{|c|}{ DV: Turnover Intention ${ }^{a}$} & \multirow{2}{*}{ VIF } \\
\hline & Model 1 & Model 2 & \\
\hline \multicolumn{4}{|l|}{ Control Variables } \\
\hline Gender & .074 & .055 & 1.029 \\
\hline Age & -.040 & .048 & 1.563 \\
\hline Education & .117 & .087 & 1.081 \\
\hline Position Tenure & -.148 & -.155 & 1.553 \\
\hline Company Tenure & $.220^{*}$ & .173 & 1.638 \\
\hline \multicolumn{4}{|l|}{ Predictor Variables } \\
\hline Communication Climate & & $-.175^{*}$ & 1.575 \\
\hline Supervisory Communication & & $-.243^{* *}$ & 1.784 \\
\hline Organizational Integration & & .152 & 2.524 \\
\hline Co-workers Communication & & .120 & 2.117 \\
\hline
\end{tabular}




\begin{tabular}{lll}
\hline Personal Feedback & $-.246^{*}$ & 2.074 \\
$\mathrm{R} 2$ & .196 & \\
Adjusted R2 & .149 & \\
$\Delta \mathrm{R} 2$ & .143 & \\
$\mathrm{~F}$ & $6.032^{* * *}$ & \\
\hline
\end{tabular}

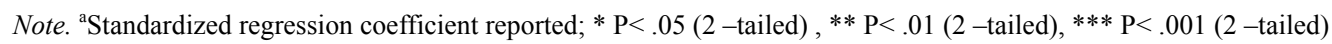

For testing the hypothesized mediations, Baron and Kenny's (1986) three steps method in combination with Sobel's test were employed. Thus, in testing the mediating role of normative commitment for the supervisory communication-turnover intention relationship, at first, turnover intention was regressed on supervisory communication. While other variables were controlled, supervisory communication showed significant association with turnover intention $(\beta=-.243, \mathrm{P}<.01$; see Table 4$)$. In the 2 nd step, normative commitment was regressed on supervisory communication. Since there was no significant link between these two variables, mediating role of normative commitment for supervisory communication-turnover intention relationship was not possible. So, there was no point in proceeding to the next step.

Table 4. The Result of hierarchical multiple regression for assessing the mediating role of normative commitment for supervisory communication-turnover intention relationship

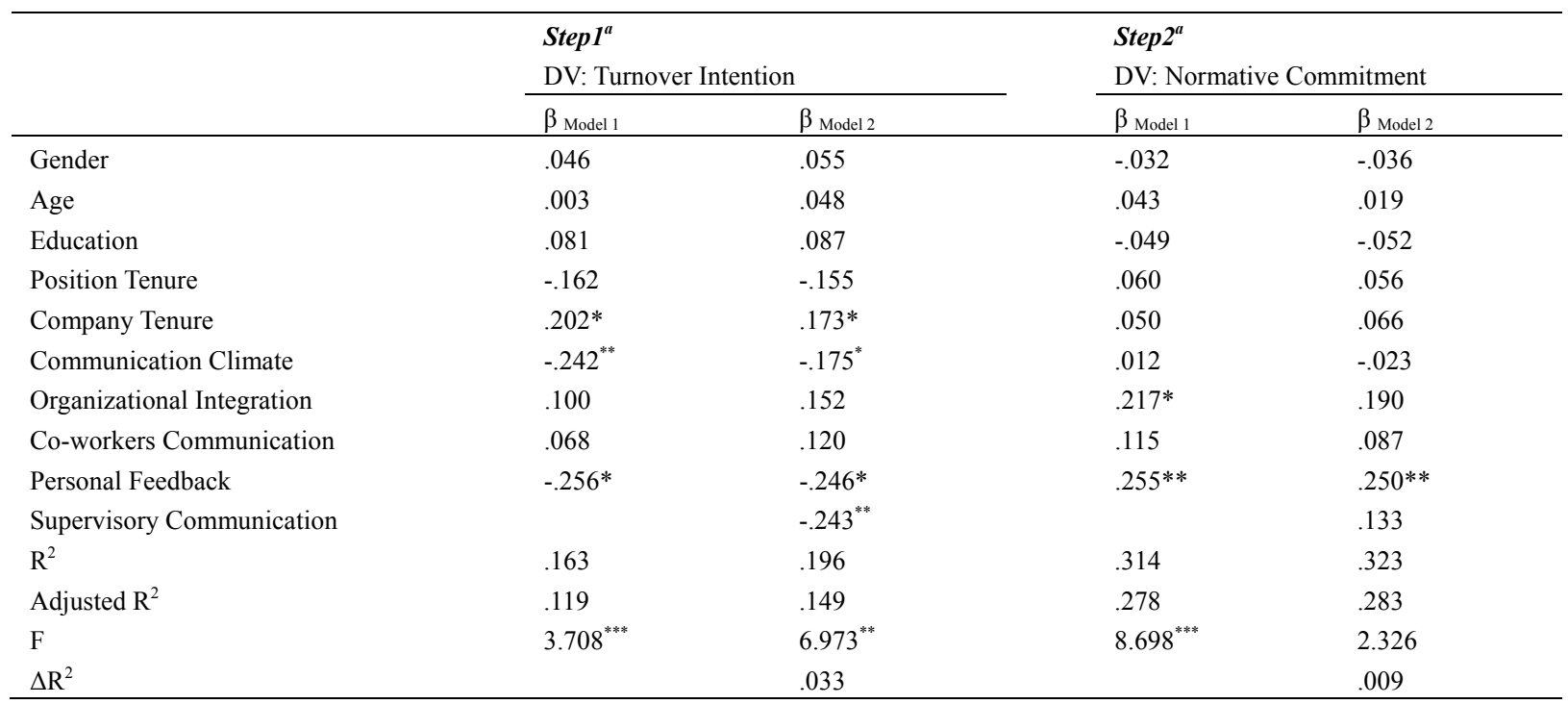

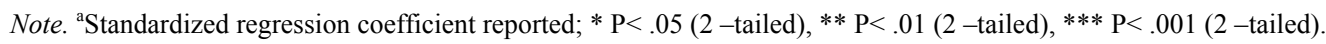

For assessing the mediating role of affective commitment for the relationship between supervisory communication and turnover intention, the same procedure was followed. First, supervisory communication was significantly related to turnover intention $(\beta=-.243, \mathrm{P}<.01)$. Second, supervisory communication was found to be significantly related to affective commitment $(\beta=.163, \mathrm{P}<.05)$. In the 3rd step, turnover intention was regressed on affective commitment while controlling for supervisory communication along with other independent variables and demographics (see Table 5). The result provided evidence for significant association between affective commitment and turnover intention $(\beta=-.172, \mathrm{P}<.05)$.

Since supervisory communication in both models (i.e., Model 1 and 2 in Table 5) were significant, thus it can be concluded that affective commitment partially mediates supervisory communication-turnover intention relationship. The result of Sobel's test also indicated that the relationship between supervisory communication and turnover intention has been significantly reduced after the inclusion of affective commitment.

During the first step of testing the mediating role of affective commitment for the relationship between organizational integration and turnover intention, no significant association between organizational integration and turnover intention was observed (see Table 6). Since there is no significant relationship, therefore no mediation for the relationship was possible. 
Table 5. The result of hierarchical multiple regression for assessing the mediating role of affective commitment for supervisory communication-turnover intention relationship

\begin{tabular}{|c|c|c|c|c|c|c|}
\hline & \multicolumn{2}{|c|}{$\begin{array}{c}\text { Step1 }^{a} \\
\text { DV: Turnover Intention }\end{array}$} & \multicolumn{2}{|c|}{$\begin{array}{c}\text { Step }^{a}{ }^{a} \\
\text { DV: Affective Commitment }\end{array}$} & \multicolumn{2}{|c|}{$\begin{array}{c}\text { Step }^{a} \\
\text { DV: Turnover Intention }\end{array}$} \\
\hline & $\beta_{\text {Model 1 }}$ & $\beta_{\text {Model } 2}$ & $\beta_{\text {Model 1 }}$ & $\beta_{\text {Model } 2}$ & $\beta_{\text {Model } 1}$ & $\beta_{\text {Model 2 }}$ \\
\hline Gender & .046 & .055 & .059 & .053 & .055 & .064 \\
\hline Age & .003 & .048 & .018 & -.013 & .048 & .046 \\
\hline Education & .081 & .087 & -.021 & -.025 & .087 & .082 \\
\hline Position Tenure & -.162 & -.155 & .093 & .088 & -.155 & -.140 \\
\hline Company Tenure & $.202 *$ & $.173^{*}$ & .097 & .116 & .173 & $.193^{*}$ \\
\hline Communication Climate & $-.242^{* *}$ & $-.175^{*}$ & $.314^{* * *}$ & $.269^{* *}$ & $-.175^{*}$ & -.129 \\
\hline Organizational Integration & .100 & .152 & .151 & .116 & .152 & .172 \\
\hline Co-workers Communication & .068 & .120 & .158 & .123 & .120 & .141 \\
\hline Personal Feedback & $-.256^{*}$ & $-.246^{*}$ & .045 & .038 & $-.246^{*}$ & $-.240^{*}$ \\
\hline Supervisory Communication & & $-.243^{* *}$ & & $.163^{*}$ & $-.243^{* *}$ & $-.215^{*}$ \\
\hline Affective Commitment & & & & & & $-.172^{*}$ \\
\hline $\mathrm{R}^{2}$ & .163 & .196 & .343 & .358 & .196 & .215 \\
\hline Adjusted $\mathrm{R}^{2}$ & .119 & .149 & .308 & .320 & .149 & .164 \\
\hline F & $3.708^{* * *}$ & $6.973^{* *}$ & $9.911 * * *$ & $3.917^{*}$ & $4.151^{* *}$ & $4.110^{*}$ \\
\hline$\Delta \mathrm{R}^{2}$ & & .033 & & .015 & & .019 \\
\hline
\end{tabular}

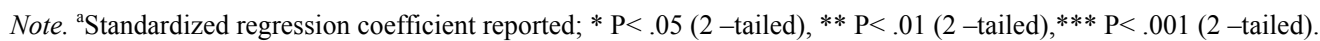

Table 6. Theresult of hierarchical multiple regression for assessing the mediating role of affective commitment for organizational integration-turnover intention relationship

\begin{tabular}{lcc}
\hline & \multicolumn{2}{c}{ Step1 } \\
& \multicolumn{2}{c}{ DV: Turnover Intention } \\
\cline { 2 - 3 } & $\beta_{\text {Model } 1}$ & $\beta_{\text {Model } 2}$ \\
\hline Gender & .066 & .055 \\
Age & .046 & .048 \\
Education & .087 & .087 \\
Position Tenure & -.164 & -.155 \\
Company Tenure & $.185^{*}$ & $.173^{*}$ \\
Communication Climate & -.150 & $-.175^{*}$ \\
Supervisory Communication & $-.219^{*}$ & $-.243^{* *}$ \\
Co-workers Communication & .172 & .120 \\
Personal Feedback & $-.199^{*}$ & $-.246^{*}$ \\
Organizational Integration & & -.152 \\
$\mathrm{R}^{2}$ & .187 & .196 \\
Adjusted $\mathrm{R}^{2}$ & .144 & .149 \\
$\mathrm{~F}$ & $4.374^{* * *}$ & 1.933 \\
$\Delta \mathrm{R}^{2}$ & & .009 \\
\hline
\end{tabular}

Note. ${ }^{a}$ Standardized regression coefficient reported; ${ }^{*} \mathrm{P}<.05$ ( 2 -tailed), ${ }^{* *} \mathrm{P}<.01$ ( 2 -tailed $),{ }^{* * *} \mathrm{P}<.001$ ( 2 -tailed).

\section{Discussion and Limitation}

Among the hypothesized communication satisfaction's dimensions, personal feedback (H1), supervisory communication (H2), and communication climate (H7) were identified as significant antecedents of turnover intention. According to the result, personal feedback showed the strongest association with turnover intention. The strong relationship between these two variables can be justified by the fact that understanding the level of performance reduces and alleviates employees' work-related anxiety and stress (Spector \& Jex, 1991) and also makes them more empowered (Liao et al., 2009). Among the three hypothesized mediations, supervisory communication-turnover intention relationship was found to be partially mediated by affective commitment (H4). In other words, upward and downward flows of information influence the employees' emotional attachment to the organization, which in turn affect the employees' decision for leaving the organization. 
Obviously there are some limitations in this study. First, employing a non-probability sampling method (i.e., quota sampling) may have had a negative influence on the result. Second, despite the fact that Harman's single factor test indicated that common method bias was not problematic; the usage of self-assessed measures may still have introduced some bias into the data.

\section{Conclusion and Future Research}

It could be concluded that proper communication in the organization can significantly decrease the undesirable turnovers. By providing employees with just-in-time feedback, supervisors can ameliorate their level of stress caused by role ambiguity and thereby reduce the chance of turnover. Moreover, redesigning the organizational processes in a way that facilitate the communication throughout the organization can also have significant impact on employee retention. It is recommended for future research to incorporate some moderators such as cultural factors and the new construct of "suspicion" (i.e., individual's uncertainty and perceived malintent about the information, which is electronically sent, analyzed, generated, or implemented; Bobko et al., 2014) into the current framework.

\section{References}

Allen, D. G., Bryant, P. C., \& Vardaman, J. M. (2010). Retaining Talent: Replacing Misconceptions With Evidence-Based Strategies. Academy of Management Perspectives, 48-64.

Allen, N. J., \& Meyer, J. P. (1990). The measurement and antecedents of affective, continuance and normative commitment to the organization. Journal of Occupational Psychology, 1-18. http://dx.doi.org/10.1111/j.2044-8325.1990.tb00506.x

Ballinger, G., Craig, E., Cross, R., \& Gray, P. (2011). A stitch in time saves nine: leveraging networks to reduce the costs of turnover. California Management Review, 111-133.

Baron, R. M., \& Kenny, D. A. (1986). The Moderator-Mediator Variable Distinction in Social Psychological Research: Conceptual, Strategic, and Statistical Considerations. Journal of Personality and Social Psychology, 1173-1182. http://dx.doi.org/10.1037/0022-3514.51.6.1173

Bobko, P., Barelka, A. J., \& Hirshfield, L. M. (2014). The Construct of State-Level Suspicion: A Model and Research Agenda for Automated and Information Technology (IT) Contexts. Human Factors, 489-508. http://dx.doi.org/10.1177/0018720813497052

Borneo Post Online. (2011). Retrieved from Tower Watson survey reveals attrition rate to double in 2011, 16 percent increase from last year. Retrieved from http://www.theborneopost.com/2011/11/18/tower-watson-survey-reveals-attrition-rate-to-double-in-2011-16 -pct-increas

Brunetto, Y., Farr-Wharton, R., \& Shacklock, K. (2011). Supervisor-subordinate communication relationships, role ambiguity, autonomy and affective commitment for nurses. Contemporary Nurse: A Journal for the Australian Nursing Profession, 227-239. http://dx.doi.org/10.5172/conu.2011.227

Cascio, W. F. (2006). The Economic Impact of Employee Behaviors on Organizational Performance. California Management Review, 41-59.

Cox, S. A. (1999). Group Communication and Employee Turnover: How Coworkers Encourage Peers to Voluntarily Exit. Southern Communication Journal, 181-192. http://dx.doi.org/10.1080/10417949909373133

Deconinck, J., Johnson, J., Busbin, J., \& Lockwood, F. (2008). An examination of the validity of the downs and hazen communication satisfaction questionnaire. Marketing Management Journal, 145-153.

Dess, G. G., \& Shaw, J. D. (2001). Voluntary turnover, social capital, and organizational performance. Academy of Management Review, 446-456. http://dx.doi.org/10.5465/AMR.2001.4845830

Downs, C. W., \& Hazen, M. D. (1977). A Factor Analytic Study of Communication Satisfaction. The Journal of Business Communication, 63-73. http://dx.doi.org/10.1177/002194367701400306

Fish, E. H. (1917).Human engineering. Journal of Applied Psychology, 161-174.

Greenwood, M. (1919). Problems of industrial organisation. Journal of the Royal Statistical Society, 186-221.

Griffeth, R. W., Hom, P. W., \& Gaertner, S. (2000). A Meta-Analysis of Antecedents and Correlates of Employee Turnover: Update, Moderator Tests, and Research Implications for the Next Millennium. Journal of Managemen, 463-488. http://dx.doi.org/10.1177/014920630002600305 
Hackman, J. R., \& Oldham, G. R. (1975). Development of the Job Diagnostic Survey. Journal of Applied Psychology, 159-170.

Hancock, J. I., Allen, D. G., Bosco, F. A., McDaniel, K. R., \& Pierce, C. A. (2013). Meta-Analytic Review of Employee Turnover as a Predictor of Firm Performance. Journal of Management, 573-603. http://dx.doi.org/10.1177/0149206311424943

Hausknecht, J. P., \& Trevor, C. O. (2011). Collective Turnover at the Group, Unit, and Organizational Levels: Evidence, Issues, and Implications. Journal of Management, 352-388. http://dx.doi.org/10.1177/0149206310383910

Heavey, A. L., Holwerda, J. A., \& Hausknecht, J. P. (2013). Causes and Consequences of Collective Turnover: A Meta-Analytic Review. Journal of Applied Psychology.

Hecht, M. L. (1978). Measures of communication satisfaction. Human Communication, 350-368. http://dx.doi.org/10.1111/j.1468-2958.1978.tb00721.x

Hill, S. K., \& Northouse, P. G. (1978). A Research Design for Studying Communication Climate within a Organization. Journal of Business Communication, 37-44. http://dx.doi.org/10.1177/002194367801500205

Holtom, B. C., Mitchell, T. R., Lee, T. W., \& Eberly, M. B. (2008). Turnover and Retention Research: A Glance at the Past, a Closer Review of the Present, and a Venture into the Future. Academy of Management Annals, 231-274. http://dx.doi.org/10.1080/19416520802211552

Jaros, S. (2007). Meyer and Allen Model of Organizational Commitment: Measurement Issues. Journal of Organizational Behavior, 7-25.

Kanter, R. M. (1968). Commitment and Social Organization: A Study of Commitment Mechanisms In Utopian Communities. American Sociological Review, 499-517. http://dx.doi.org/10.2307/2092438

Kim, S. (2012). The Impact of Human Resource Management on State Government IT Employee Turnover Intentions. Public Personnel Management, 257-279. http://dx.doi.org/10.1177/009102601204100204

Liao, H., Toya, K., Lepak, D. P., \& Hong, Y. (2009). Do They See Eye to Eye? Management and Employee Perspectives of High-Performance Work Systems and Influence Processes on Service Quality. Journal of Applied Psychology, 371-391. http://dx.doi.org/10.1037/a0013504

March, J., \& Simon, H. (1958). Organizations. New York: John Wiley.

Martin, J. T. (1979). A Contextual Model of Employee Turnover Intentions. Academy of Management Journal, 313-324. http://dx.doi.org/10.2307/255592

Mathieu, J., \& Zajac, D. (1990). A Review and Meta-Analysis of the Antecedents, Correlates, and Consequences of Organizational Commitment. Psychological Bulletin, 171-194.

McKnight, D. H., Phillips, B., \& Hardgrave, B. C. (2009). Which reduces IT turnover intention the most: Workplace characteristics or job characteristics? Information \& Management, 167-174. http://dx.doi.org/10.1016/j.im.2009.01.002

Meyer, J. P., \& Allen, N. J. (1997). Commitment in the Workplace: Theory, Research, and Application. Sage Publications. http://dx.doi.org/10.1002/hrdq.3920090309

Meyer, J. P., Stanley, D. J., Herscovitch, L., \& Topolnytsky, L. (2002). Affective, Continuance, and Normative Commitment to the Organization: A Meta-analysis of Antecedents, Correlates, and Consequences. Journal of Vocational Behavior, 20-52. http://dx.doi.org/ 10.1006/jvbe.2001.1842

Mowday, R. T., Steers, R. M., \& Porte, L. W. (1979). The measurement of organizational commitment. Journal of Vocational Behavior, 224-247. http://dx.doi.org/10.1016/0001-8791(79)90072-1

Mueller, B. H., \& Lee, J. (2002). Leader-Member Exchange and Organizational Communication Satisfaction in Multiple Contexts. Journal of Business Communication, 220-244. http://dx.doi.org/10.1177/002194360203900204

Pare, G., \& Tremblay, M. (2007). The Influence of High-Involvement Human Resources Practices, Procedural Justice, Organizational Commitment, and Citizenship Behaviors on Information Technology Professionals' $\begin{array}{llll}\text { Turnover Intentions. Group \& Organization } & \text { Management, 326-357. }\end{array}$ http://dx.doi.org/10.1177/1059601106286875

Shaw, J. D., Delery, J. E., Jenkins, J. G., \& Gupta, N. (1998). An Organization-Level Analysis of Voluntary and Involuntary Turnover. Academy of Management Journal, http://dx.doi.org/10.2307/256939 
Shaw, J. D., Duffy, M. K., Johnson, J. L., \& Lockhart, D. E. (2005). Turnover, Social Capital Losses, and Performance. Academy of Management Journal, 594-606. http://dx.doi.org/10.5465/AMJ.2005.17843940

Spector, P. E., \& Jex, S. M. (1991). Relations of Job Characteristics From Multiple Data Sources With Employee Affect, Absence, Turnover Intentions, and Health. Journal of Applied Psychology, 46-53. http://dx.doi.org/10.1037/0021-9010.76.1.46

Summers, J. K., Humphrey, S. E., \& Ferris, G. R. (2012). Team Member Change, Flux in Coordination, and Performance: Effects of Strategic Core Roles, Information Transfer, and Cognitive Ability. Academy of Management Journal, 314-338. http://dx.doi.org/10.5465/amj.2010.0175

Timm, P. R. (1978). Worker Responses To Supervisory Communication Inequity: an Exploratory Study. Journal of Business Communication, 11-24. http://dx.doi.org/ 10.1177/002194367801600102

Tourangeau, A., Granley, L., Spence Laschinger, H. K., \& Pachis, J. (2010). Relationships among leadership practices, work environments, staff communication and outcomes in long-term care A. Tourangeau et al. Relationships in long-term care. Journal of Nursing Management, 1060-1072. http://dx.doi.org/10.1111/j.1365-2834.2010.01125.x

Tsai, M. T., Chuang, S. S., \& Hsieh, W. P. (2009). An integrated process model of communication satisfaction and organizational outcomes. Social Behavior \& Personality: an International Journal, 825-834. http://dx.doi.org/10.2224/sbp.2009.37.6.825

\section{Copyrights}

Copyright for this article is retained by the author(s), with first publication rights granted to the journal.

This is an open-access article distributed under the terms and conditions of the Creative Commons Attribution license (http://creativecommons.org/licenses/by/3.0/). 